\title{
Prevention and Treatment of Severe Hemodynamic Compromise in Pediatric Heart Transplant Patients
}

\author{
John M. Costello ${ }^{1,2}$ and Elfriede Pahl ${ }^{2}$
}

1 Division of Pulmonary and Critical Care Medicine, Department of Pediatrics, The Children's Memorial Hospital, Feinberg School of Medicine at Northwestern University, Chicago, Illinois, USA

2 Division of Cardiology, Department of Pediatrics, The Children's Memorial Hospital, Feinberg School of Medicine at Northwestern University, Chicago, Illinois, USA

\section{Contents}

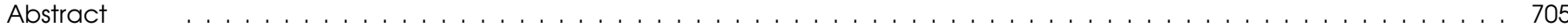

1. Prevention of Rejection: An Overview of Immunosuppression . . . . . . . . . . . . . . . . . . . . . . . . . 706

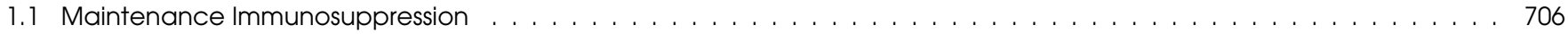

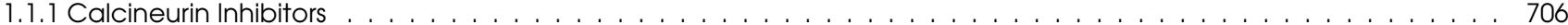

1.1 .2 Antiproliferative Agents . . . . . . . . . . . . . . . . . . . . . . . . . . . . 707

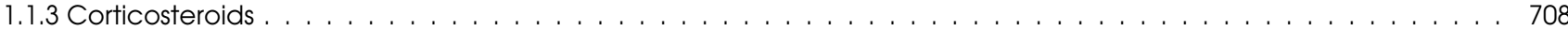

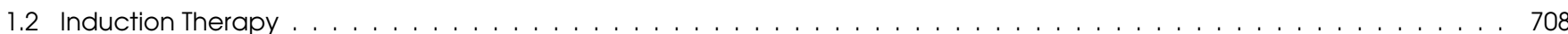

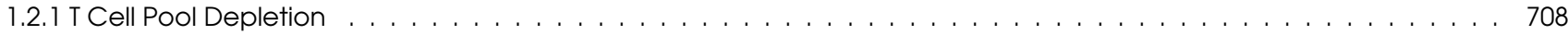

1.2.2 Monoclonal Antibodies Against Interleukin-2 Receptors . . . . . . . . . . . . . . . . . . . . . . . . . . . . . . . . . 709

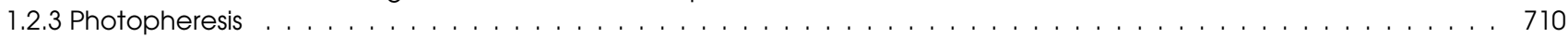

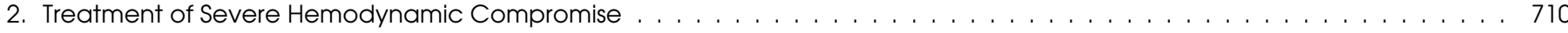

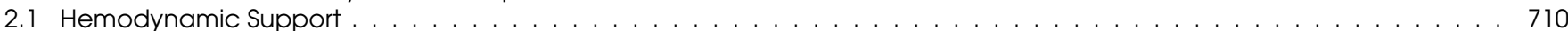

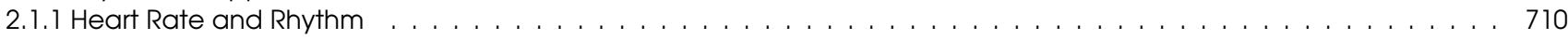

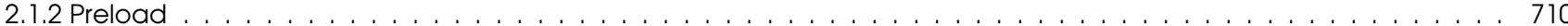

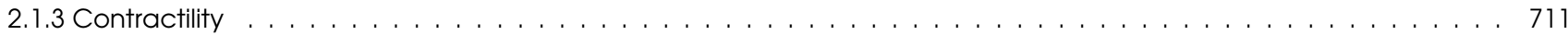

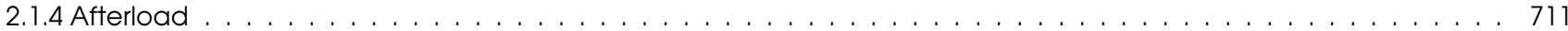

2.1 .5 Oxygen Consumption $\ldots \ldots \ldots \ldots \ldots \ldots$

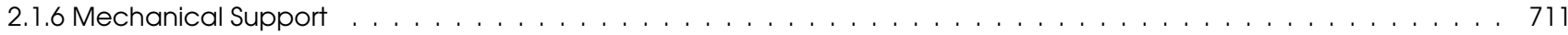

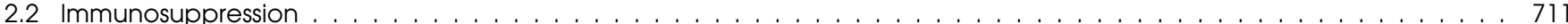

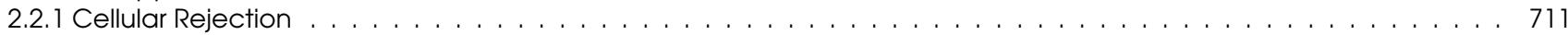

2.2 .2 Humoral Rejection $\ldots \ldots \ldots \ldots \ldots \ldots$

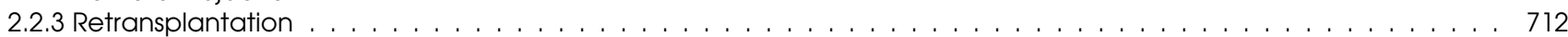

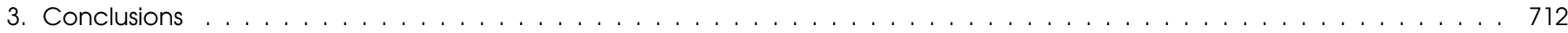

\section{Abstract}

Allograft rejection is a leading cause of severe hemodynamic compromise in pediatric heart transplant patients. A triple-drug immunosuppression regimen, which includes a calcineurin inhibitor, antiproliferative agent, and corticosteroid, suppresses the immune system at multiple different levels for optimal graft protection while minimizing the adverse effects of any one particular agent. Some pediatric centers also use induction therapy with anti-T cell antibodies immediately following transplantation as additional rejection prophylaxis. These antibodies augment immunosuppression by either depleting the $\mathrm{T}$ cell pool or blocking interleukin- 2 receptors on activated $\mathrm{T}$ cells.

Despite the aggressive preventive measures outlined above, some pediatric heart transplant patients will develop severe hemodynamic compromise, most commonly due to fulminant rejection. Such patients require attention to, and optimization of, the four determinants of cardiac output (heart rate, preload, contractility and afterload) to stabilize the circulation until the rejection can be reversed. Careful administration of volume, diuretics, inotropes, and afterload-reducing agents will meet this goal. Patients with allograft rejection require augmentation of immune suppression to facilitate myocardial recovery. 
Corticosteroids form the cornerstone of treatment for both cellular and vascular rejection. In patients with refractory cellular rejection, conversion to mycophenolate mofetil or tacrolimus may be appropriate if these agents are not already being used for maintenance immunosuppression. Critically ill patients may additionally benefit from muromonab-CD3 (OKT3) to augment lympholysis. Treatment employed specifically for humoral rejection is prescribed with the intention of suppressing new antibody formation, removing circulating antibody, and improving coronary blood flow. In addition to corticosteroids, cyclophosphamide and antithymocyte globulin or muromonab-CD3, along with plasmapheresis, may improve survival. Systemic heparinization should be considered to minimize coronary thrombosis in patients with humoral rejection. In the future, novel immunosuppressive agents may further assist in the prevention as well as treatment of severe hemodynamic compromise due to rejection in pediatric heart transplant recipients.

The development of severe hemodynamic compromise in pediatric heart transplant patients is associated with significant morbidity and mortality. ${ }^{[1]}$ A primary objective of medical personnel treating these patients is to prevent acute graft failure and the obligatory hemodynamic compromise that follows. To achieve this goal, a dedicated team including multiple physicians (with expertise in transplantation, cardiac catheterization, echocardiography, pathology, electrophysiology and critical care), nurse specialists, pharmacists, social workers, mental health professionals and, perhaps most importantly, the patient and family members, must work in unison over the lifetime of the patient.

Severe hemodynamic compromise may occur in the pediatric heart transplant patient from a variety of etiologies, most commonly secondary to allograft rejection or transplant coronary artery disease (TCAD). Meticulous evaluation and education of the patient and his/her caretakers before, during and following heart transplantation will minimize the chances of hemodynamic embarrassment, since late rejection in children is commonly associated with noncompliance. ${ }^{[2]}$ This review will focus on the role of immunotherapy for the prevention and treatment of rejection in pediatric heart transplant recipients, as well as drugs and other modalities used to support the circulation in such patients with severe hemodynamic compromise. This review will not include discussion of pretransplant factors, including pulmonary hypertension, elevated panel reactive antibody, and patient-donor graft matching, as well as post-transplant issues of primary graft failure and TCAD.

Due to the limited number of pediatric heart transplants performed at any one center, the initial experience and clinical research for all of the drugs discussed in this review came from adult heart and other solid organ transplant recipients.

\section{Prevention of Rejection: An Overview of Immunosuppression}

\section{1 Maintenance Immunosuppression}

In the absence of adequate immunosuppression, antigens from the allograft will be recognized by recipient CD4 T cells as foreign, triggering a host response that eventually leads to rejection (figure 1). The ideal immunosuppressive agent - one that selectively inhibits alloantigen immune responses, prevents chronic allograft rejection, and is free of major adverse effects - does not yet exist. ${ }^{[3]}$ Most pediatric programs currently use triple-drug immunosuppression regimens in the immediate postoperative period extending through at least the first 6 months following heart transplantation to prevent rejection (table I). The combination of a calcineurin inhibitor, antiproliferative agent, and corticosteroid suppresses the immune system at multiple different levels for optimal graft protection and minimizes the adverse effects of any one particular agent (figure 2). Intense immunosuppression is achieved immediately following transplant, when the risk of rejection is highest, and then tapered over the subsequent weeks and months, depending on the perceived risk of rejection for each individual patient. Generally, the same drugs administered immediately following transplant are also used for long-term immunosuppression, but at lower doses.

\subsubsection{Calcineurin Inhibitors}

Calcineurin is a key enzyme that is situated early in the signal transduction pathway between the $\mathrm{T}$ cell receptor and the interleukin (IL)-2 gene. Cyclosporine inhibits calcineurin, ${ }^{[4]}$ thus preventing the production of IL-2 and $\gamma$-interferon, effectively interrupting the $\mathrm{T}$ cell activation cascade. ${ }^{[5]}$ Cyclosporine has served as the cornerstone for solid organ transplant immunosuppression for more than two decades and is widely used by pediatric heart transplant centers. Problems with variable absorption of the Sandimmune $^{\circledR 1}$ brand of cyclosporine have been diminished with the introduction of a microemulsion formulation marketed as Neoral ${ }^{\circledR}$ (Novartis). ${ }^{[6-8]}$ Generic forms of cyclosporine are under development.

Tacrolimus, another calcineurin inhibitor, has a similar mechanism of action to cyclosporine, but greater potency. ${ }^{[4]}$ Tacrolimus is used by a few pediatric heart transplant centers in place of cyclo-

1 The use of tradenames is for product identification purposes only and does not imply endorsement. 


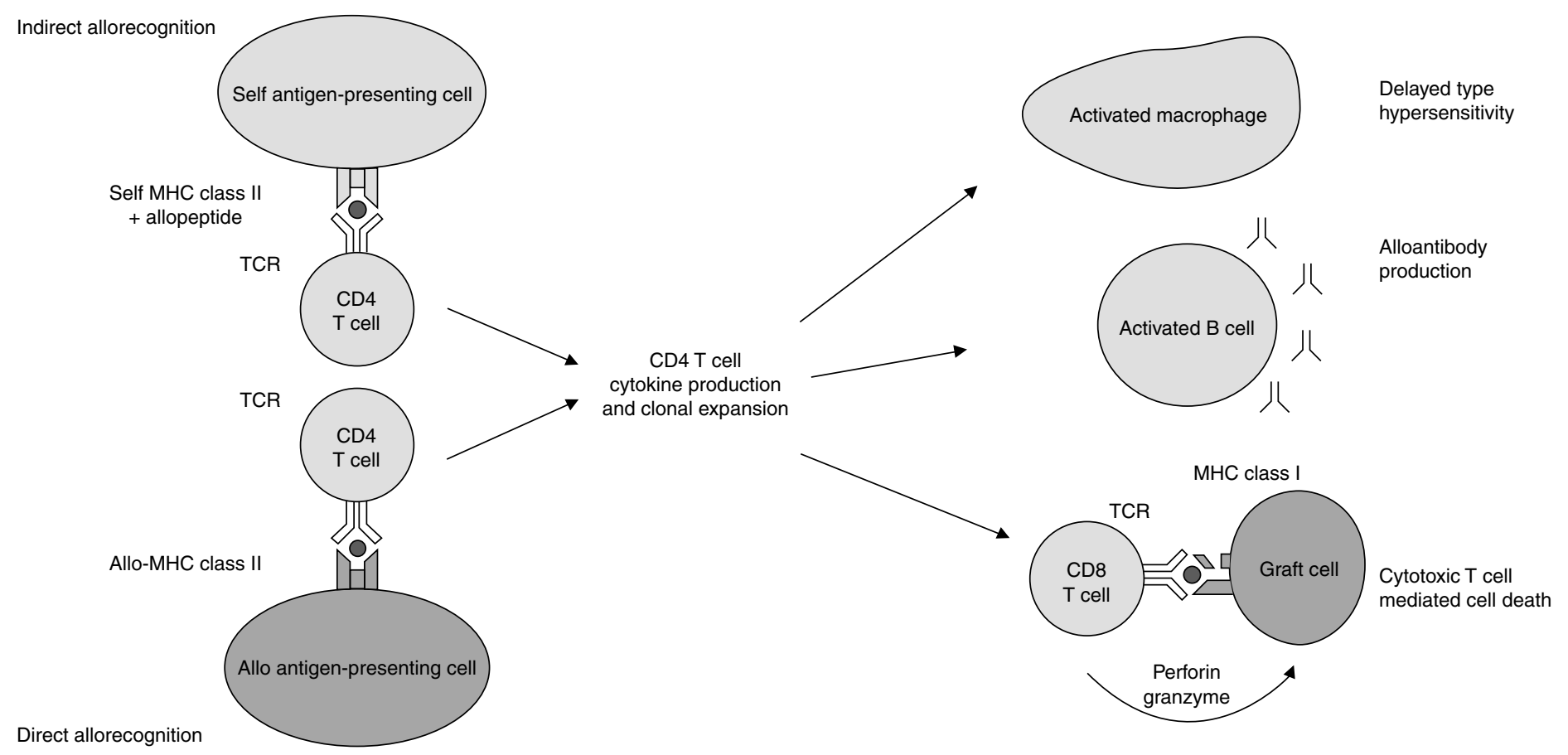

Fig. 1. Cellular interactions that form the anti-allograft response: CD4 T cells recognize antigen through direct and indirect pathways, become agitated, and undergo clonal proliferation. Activated CD4 T cells provide help for monocyte/macrophages, B cells, and cytotoxic CD8 T cells by secreting cytokines and by cell-cell contact-dependent mechanisms. Activated monocytes/macrophages release a range of noxious agents that mediate tissue injury. B cell alloantibody production ultimately results in complement mediated tissue destruction. Activated CD8 T cells kill graft cells in an antigen-specific manner through induction of apoptosis and cell lysis (reproduced from Denton et al. ${ }^{\left[{ }^{[3]}\right.}$ with permission). $\mathbf{M H C}=$ major histocompatibility complex; $\mathbf{T C R}=\mathrm{T}$ cell receptor.

sporine for initial maintenance immunotherapy, but tacrolimus is not approved by the US Food and Drug Administration for use in heart transplant recipients. Other programs may switch patients from cyclosporine to tacrolimus due to persistent rejection or unacceptable adverse effects of cyclosporine. In a multicenter trial comparing cyclosporine to tacrolimus in adult heart transplant recipients, less hypertension and hyperlipidemia were seen with tacrolimus. ${ }^{[9]}$ Because tacrolimus is associated with other toxicities, including anemia, renal insufficiency, and type 1 diabetes mellitus, ${ }^{[10-12]}$ most programs continue to prefer cyclosporine for primary therapy. ${ }^{[13]}$ Plasma levels of tacrolimus should be followed closely to avoid toxicity, particularly when the drug is administered intravenously. ${ }^{[14]}$

\subsubsection{Antiproliferative Agents}

Antiproliferative agents prevent the expansion of alloactivated $\mathrm{T}$ and $\mathrm{B}$ cell clones. Azathioprine is a thiopurine which, following conversion to mercaptopurine, antagonizes several enzymes necessary for purine synthesis, thus inhibiting DNA and RNA production. Available since the 1960s, azathioprine may cause significant bone marrow suppression and is being used less often since the introduction of mycophenolate mofetil.
Mycophenolate mofetil is a prodrug of mycophenolic acid, which selectively inhibits inosine monophosphate dehydrogenase in the de novo pathway of guanine nucleotide synthesis, thus impairing proliferation of lymphocytes. ${ }^{[15,16]}$ Mycophenolate mofetil also inhibits antibody production by plasma cells ${ }^{[17]}$ and the glycosylation of lymphocyte adhesion molecules, thus reducing the binding of these cells to activated endothelial cells. ${ }^{[18]}$ When compared with adult heart transplant recipients randomized to receive azathioprine, those on mycophenolate mofetil for initial maintenance immunosuppression had less rejection and a lower 1-year mortality rate when analyzed on a treated basis; however, no difference was detected on the intention-to-treat analysis. ${ }^{[19]}$ Another study revealed no difference in adult patients randomized to mycophenolate mofetil or azathioprine 3 months following transplant in terms of rejection or early complications. ${ }^{[20]}$ Early pediatric data support a role for the use of mycophenolate mofetil in heart transplant recipients, although drug levels may need to be monitored. ${ }^{[21,22]}$ A multicenter, randomized trial will be necessary to determine if mycophenolate mofetil is superior to azathioprine.

Sirolimus is a novel immunosuppressive agent that inhibits cytokine-induced signal transduction distal to calcineurin, and 
Table I. Standard maintenance triple-drug immunotherapy

\begin{tabular}{|c|c|c|c|c|}
\hline Drug & Brand name & Starting dose & Therapeutic level (trough) & Specific adverse effects \\
\hline \multicolumn{5}{|l|}{ Calcineurin inhibitors } \\
\hline Cyclosporine & $\begin{array}{l}\text { Sandimmune } \\
\text { Neoral }^{\circledR}\end{array}$ & $\begin{array}{l}5 \mathrm{mg} / \mathrm{kg} \text { IV over } 18 \text { hours, } \\
\text { or } 0.05-0.1 \mathrm{mg} / \mathrm{kg} / \mathrm{h} \text { once } \\
\text { urine output is adequate }\end{array}$ & $\begin{array}{l}\text { Depends on assay used } \\
\text { and time since transplant }\end{array}$ & $\begin{array}{l}\text { Renal insufficiency, hypertension, seizures, } \\
\text { hyperlipidemia, gingival hyperplasia, } \\
\text { hypertrichosis }\end{array}$ \\
\hline Tacrolimus & Prograf $^{\circledR}(\mathrm{FK} 506)$ & $0.1 \mathrm{mg} / \mathrm{kg} \mathrm{IV} \mathrm{od}$ & $10-15 \mu \mathrm{g} / \mathrm{L}$ & $\begin{array}{l}\text { Renal insufficiency, anemia, diabetes, } \\
\text { vasculitis }\end{array}$ \\
\hline \multicolumn{5}{|l|}{ Anti-proliferative agents } \\
\hline Azathioprine & Imuran $^{\circledR}$ & $1-2 \mathrm{mg} / \mathrm{kg} \mathrm{PO}$ od & $\mathrm{N} / \mathrm{A}$; follow $\mathrm{CBC}$ & Bone marrow suppression \\
\hline Mycophenolate mofetil & CellCept ${ }^{\circledR}$ & 20 mg/kg PO bid & $>3 \mu \mathrm{g} / \mathrm{L} ;$ follow CBC & Vomiting, diarrhea \\
\hline Sirolimus & Rapamycin $^{\circledR}$ & & $\mathrm{N} / \mathrm{A}$; follow $\mathrm{CBC}$ & Bone marrow suppression, hyperlipidemia \\
\hline \multicolumn{5}{|l|}{ Corticosteroids } \\
\hline $\begin{array}{l}\text { Methylprednisolone, } \\
\text { prednisone }\end{array}$ & $\begin{array}{l}\text { Solu-Medrol }{ }^{\circledR}, \\
\text { Deltasone }^{\circledR}\end{array}$ & $10 \mathrm{mg} / \mathrm{kg}$ IV od, rapid taper & $\mathrm{N} / \mathrm{A}$ & $\begin{array}{l}\text { Peptic ulcer, aseptic necrosis of the hip, } \\
\text { osteoporosis, cataracts, glucose intolerance, } \\
\text { hypertension, short stature, hyperlipidemia, } \\
\text { Cushingoid features }\end{array}$ \\
\hline
\end{tabular}

a The use of tradenames is for product identification purposes only and does not imply endorsement.

bid = twice daily; $\mathbf{C B C}=$ complete blood count; $\mathbf{h}=$ hours; $\mathbf{I V}=$ intravenously; $\mathbf{N} / \mathbf{A}=$ not available; od $=$ once daily; $\mathbf{P O}=$ orally.

inhibits several kinases critical to cellular division. ${ }^{[23,24]}$ Sirolimus has been shown to decrease early rejection when used with or without calcineurin inhibitors for primary immunosuppression in adult renal transplant recipients. ${ }^{[25,26]}$ Experience with sirolimus in adult heart transplant patients is limited but suggests that the drug may allow for dose reduction or discontinuation of calcineurin inhibitors in patients with renal insufficiency. ${ }^{[27]}$ As experience with this drug grows in the adult population, it will most likely become part of the armamentarium of immunosuppressive agents used by physicians caring for pediatric heart transplant recipients, particularly those with renal compromise. However, hyperlipidemia related to sirolimus may limit widespread use of this drug in heart transplant recipients.

\subsubsection{Corticosteroids}

Corticosteroids are nonspecific anti-inflammatory agents that act by several mechanisms, including decreasing synthesis of cytokines and cell surface molecules necessary for immune function. ${ }^{[28]}$ Corticoteroids up-regulate I $\kappa \mathrm{B} \alpha$ protein synthesis, which binds nuclear factor- $\mathrm{KB}$ in the cytoplasm, preventing this key regulator of inflammatory genes from translocating to the nucleus. ${ }^{[29,30]}$ Corticoteroids also inhibit phospholipase $\mathrm{A}_{2}$ activity, thus decreasing the inflammatory response to acute rejection. Corticoteroids are used immediately after transplant by all pediatric heart transplant programs; however, continuation of low dose corticosteroids $>1$ year following transplant is controversial in the patient who has been relatively free of rejection. Due to the adverse effects of corticosteroids in growing children, and the possible association with $\mathrm{TCAD},{ }^{[13]}$ many pediatric centers at- tempt to discontinue corticosteroids within the first year following transplant. ${ }^{[31,32]}$

\subsection{Induction Therapy}

Induction therapy generally refers to the administration of anti-T cell antibodies immediately following transplantation to prevent acute rejection. These antibodies provide additional immunosuppression by either depleting the T cell pool or blocking the secretion of IL-2 from these cells. Photopheresis is an alternative induction therapy. Induction therapy is considered in patients at highest risk of rejection, such as children, sensitized patients, and those undergoing a retransplant. In addition, the use of induction therapy may allow the delayed initiation of calcineurin inhibitors in patients with renal insufficiency. ${ }^{[3]}$ Nevertheless, the generalized use of induction therapy following pediatric heart transplant is controversial as only half of the programs in the US administer an induction agent in low risk patients.

\subsubsection{T Cell Pool Depletion}

Both monoclonal and polyclonal antibody preparations may be used to effect $T$ cell pool depletion in pediatric heart transplant recipients (table II). Muromonab-CD3 (Orthoclone OKT3 ${ }^{\circledR}$ ) is a murine monoclonal antibody directed against the $\mathrm{CD} 3$ receptor on $\mathrm{T}$ cells. ${ }^{[33,34]} \mathrm{T}$ cells are rapidly cleared from the peripheral circulation following the administration of muromonab-CD3. ${ }^{[35]}$ Muromonab-CD3 also modulates the receptor complex on T cells, which inhibits their ability to recognize foreign antigens, thus inhibiting CD4 proliferation and CD8 cytotoxicity, and B cell proliferation. ${ }^{[36,37]}$ Muromonab-CD3 often causes a cytokine re- 
lease syndrome after initial doses, ${ }^{[38-41]}$ which may be minimized by pre-medication with corticosteroids, antipyretics and antihistamines. The development of human anti-mouse antibodies to muromonab-CD3 may be problematic in terms of drug efficacy and development of vascular rejection. ${ }^{[42,43]}$ When substituted for cyclosporine for the first few days following adult heart transplantation, muromonab-CD3 appeared to be equally efficacious for preventing rejection at 6 months, ${ }^{[44]}$ a strategy that allows for the delayed initiation of calcineurin inhibitors and their associated nephrotoxicity. However, other adult heart transplant programs reported that muromonab-CD3 induction therapy may be associated with an increased risk of post-transplant lymphoproliferative disease ${ }^{[45]}$ or infection. ${ }^{[46]}$ No controlled trials of muromonabCD3 for induction therapy in pediatric heart transplant recipients have been published.

Antithymocyte globulin is a polyclonal antibody preparation derived from the hyperimmune serum of animals inoculated with human thymus lymphocytes. Commercially available preparations include Thymoglubulin ${ }^{\circledR}$, which is prepared using rabbits, and $\operatorname{Atgam}{ }^{\circledR}$, which is produced using horses. Although the mechanism of action of antithymocyte globulin has not been fully elucidated, administration leads to prompt lymphocytolysis and impairment of proliferative responses of $\mathrm{T}$ cells. ${ }^{[37]}$ In the cyclosporine era, antithymocyte globulin has been used for in- duction therapy and reported in retrospective studies in adult ${ }^{[47]}$ and pediatric ${ }^{[48]}$ heart transplant recipients, and appears to be at least as efficacious as muromonab-CD3. However, because of the significant adverse effects associated with polyclonal antibody preparations and the newer, more specific and well tolerated monoclonal antibodies, the use of antithymocyte globulin is falling out of favor.

\subsubsection{Monoclonal Antibodies Against Interleukin-2 Receptors}

New induction strategies involve the administration of monoclonal antibodies against IL-2 receptors. High affinity IL-2 receptors are only functionally present on activated T cells. Monoclonal antibodies directed against these receptors will block alloantigen activated $\mathrm{T}$ cell clonal expansion and generation of cytotoxic $\mathrm{T}$ cells, while sparing resting $\mathrm{T}$ cells. ${ }^{[3]}$ Theoretically, this focused approach may minimize adverse effects of global $\mathrm{T}$ cell depletion seen with muromonab-CD3 and antithymocyte globulin.

Daclizumab and basiliximab are two commercially available chimeric mouse-human monoclonal antibodies that bind to IL-2 receptors on activated T cells. Data from well-designed adult studies on renal transplant revealed excellent tolerance and a lower incidence of cellular rejection for the initial 6 months in patients receiving basiliximab ${ }^{[49,50]}$ or daclizumab ${ }^{[51]}$ as induction agents

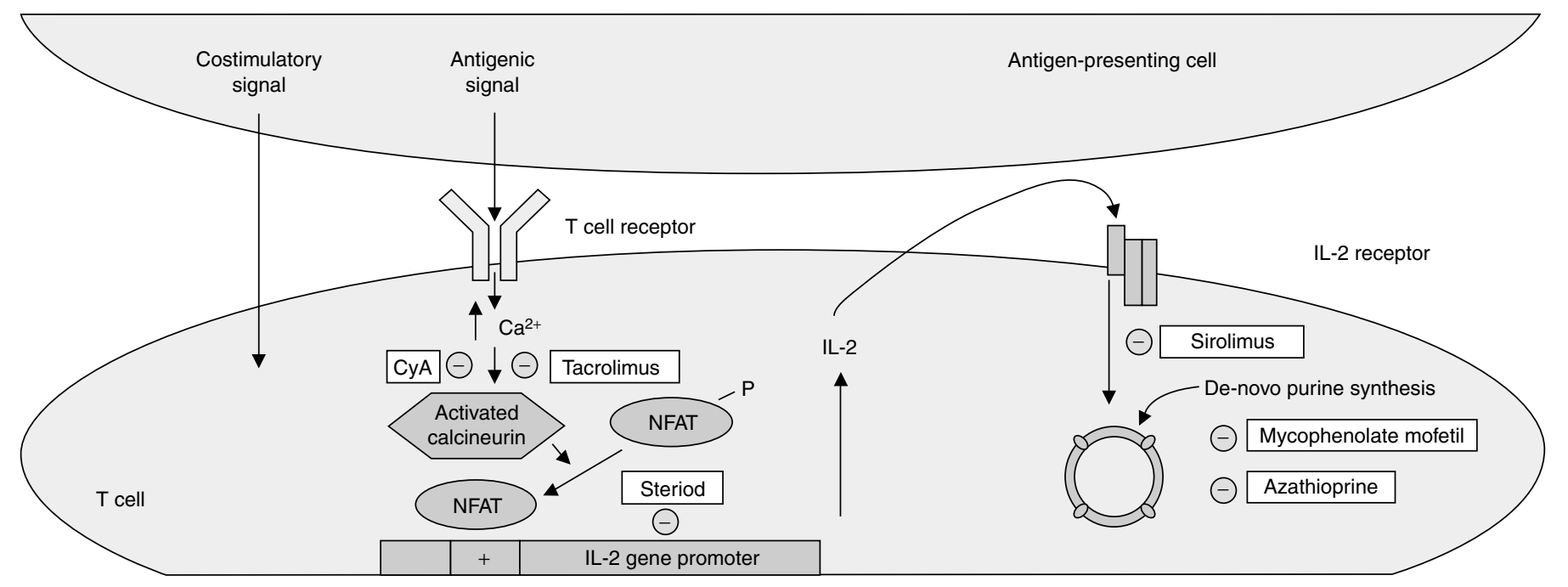

Fig. 2. Stages of T cell activation: multiple targets for immunosuppressive agents: Signal 1: stimulation of T cell receptor results in calcineurin activation, a process inhibited by cyclosporine and tacrolimus. Calcineurin dephosphorylates nuclear factor of activated T cells, enabling it to enter the nucleus and bind to the interleukin-2 promotor. Corticosteroids inhibit cytokine gene transcription in lymphocytes and antigen-presenting cells by several mechanisms. Signal 2: costimulatory signals are necessary to optimize T cell interleukin-2 gene transcription, prevent $\mathrm{T}$ cell anergy, and inhibit $\mathrm{T}$ cell apoptosis. Experimental agents, but not current immunosuppressive agents, interrupt these intracellular signals. Signal 3: interleukin-2 receptor stimulation induces the cell to enter the cell cycle and proliferate. Signal 3 may be blocked by interleukin-2 receptor antibodies or sirolimus, which inhibits second messenger signals induced by interleukin-2 receptor ligation. Following progression into cell cycle, azathioprine and mycophenolate mofetil interrupt DNA replication by inhibiting purine synthesis (reproduced from Denton et al., ${ }^{[3]}$ with permission). CyA = cyclosporine; IL-2 = interleukin-2; NFAT = nuclear factor of activated T cells; $\mathbf{P}=$ phosphate. 
Table II. Induction agents

\begin{tabular}{|c|c|c|c|}
\hline Drug & Brand name & Dose & Specific adverse effects \\
\hline \multirow[t]{2}{*}{ Muromonab-CD3 } & Orthoclone OKT3 ${ }^{\circledR a}$ & $<30 \mathrm{~kg}: 2.5 \mathrm{mg}$ IV od x 5-14 days & Cytokine release syndrome \\
\hline & & $>30 \mathrm{~kg}: 5 \mathrm{mg}$ IV od $\times 5-14$ days & \\
\hline \multirow[t]{2}{*}{ Antithymocyte globulin } & Atgam $^{\circledR}$ & $5-15 \mathrm{mg} / \mathrm{kg}$ IV od $\times$ 7-14 days & Phlebitis, fever/chills, thrombocytopenia, serum sickness, anaphylaxis \\
\hline & Thymoglobulin ${ }^{\circledR}$ & $1.5 \mathrm{mg} / \mathrm{kg}$ IV od $x$ 7-14 days & \\
\hline Basilixumab & Simulect ${ }^{\circledR}$ & $12 \mathrm{mg} / \mathrm{m}^{2} /$ dose IV on POD 0 and 4 & None reported \\
\hline Daclizumab & Zenapax ${ }^{\circledR}$ & $\begin{array}{l}1 \mathrm{mg} / \mathrm{kg} \text { IV within } 24 \mathrm{~h} \text { of transplant, } \\
\text { q2wk x five total doses }\end{array}$ & None reported \\
\hline
\end{tabular}

in addition to cyclosporine based immunotherapy. In a controlled study of adult heart transplant recipients, daclizumab decreased the incidence and severity of rejection, and was well tolerated without cytokine release syndrome or an increased incidence of infection or post-transplant lymphoproliferative disorder. ${ }^{[52]} \mathrm{We}$ have been using basiliximab as induction therapy for all pediatric heart transplant recipients at our institution since January 2001 because of the more favorable administration schedule (see table II). The efficacy of daclizumab and basilixumab when combined with tacrolimus and/or mycophenolate mofetil in heart transplant recipients is unknown at this time.

\subsubsection{Photopheresis}

Photopheresis is an alternative induction technique available at selected medical centers. Patient leucocytes are extracorporeally exposed to ultraviolet light and methoxalen, and then reinfused into the patient, where the irradiated leucocytes die over a few weeks and also cause an autologous suppressor response to nonirradiated T cells of similar clones. ${ }^{[53]}$ Preliminary adult data have shown that adding photopheresis to standard triple-drug immunosuppression may decrease rejection in the first 6 months following heart transplantation, and may inhibit the development of transplant coronary artery disease. ${ }^{[54,55]}$ Photopheresis for induction therapy for pediatric heart transplant patients has not been reported.

\section{Treatment of Severe Hemodynamic Compromise}

Despite the aggressive measures outlined above, $11 \%$ of pediatric heart transplant patients will develop late severe hemodynamic compromise, most commonly due to fulminant rejection. ${ }^{[1,56]}$ This clinical scenario represents a medical emergency as such patients are at high risk of mortality irrespective of age, biopsy score, or time from transplant. These patients should be stabilized at outlying medical facilities and then transported as soon as feasible to pediatric tertiary care centers with expertise in heart transplantation and critical care medicine. In patients with suspected fulminant rejection and hemodynamic compromise, the administration of high dose intravenous corticosteroids should not be delayed until a definitive diagnosis is made by echocardiogram or myocardial biopsy.

\section{1 Hemodynamic Support}

Cardiogenic shock represents a state of imbalance between oxygen delivery and consumption; thus, interventions are undertaken to improve cardiac output and oxygen delivery while minimizing oxygen consumption. As in any other patients with cardiogenic shock, pediatric heart transplant patients with severe hemodynamic compromise require immediate attention and optimization of the four determinants of cardiac output: heart rate, preload, contractility and afterload. ${ }^{[57]}$ Additional efforts are directed at decreasing oxygen consumption so that a balance is maintained between supply and demand. The use of invasive hemodynamic monitoring is critical for optimal resuscitation of these patients.

\subsubsection{Heart Rate and Rhythm}

Pediatric heart transplant recipients with rejection may develop significant tachyarrhythmias or bradyarrhythmias. Tachyarrhythmias may be particularly poorly tolerated in a patient with TCAD and limited coronary flow reserve. ${ }^{[58]}$ An accurate diagnosis is obtained using electrocardiograms occasionally aided by transesophageal recordings. Although beyond the scope of this article, pharmacologic and/or electrical treatment of these arrhythmias is similar to the principles that would be applied to nontransplant patients. ${ }^{[59]}$

\subsubsection{Preload}

The Frank-Starling mechanism describes the relationship between preload and stroke volume. Optimal overlap of actin and myosin filaments, or end diastolic stretch, will maximize stroke volume. ${ }^{[60]}$ Preload is estimated using central venous or SwanGanz pulmonary artery catheters. In the underfilled ventricle, crystalloid or colloid is used to increase preload. In patients who 
have volume overload, loop diuretics are administered to decrease preload.

\subsubsection{Contractility}

Contractility is the load-independent ability of muscle to generate force. ${ }^{[6]}$ Contractility is extremely difficult to accurately measure in the clinical setting as commonly used estimates of cardiac function are effected by loading conditions. Nonetheless, contractility is usually estimated by echocardiography, and may be augmented by using one, or a combination of the intravenous inotropes listed in table III. ${ }^{[61-67]}$ These agents are initiated and titrated with a goal of increasing contractility, decreasing afterload, and avoiding excessive tachycardia.

\subsubsection{Afterload}

In the intact ventricle, afterload is the sum of wall stress and vascular impedance, both of which are impractical to measure in the clinical setting. ${ }^{[60]}$ In the failing heart, increased afterload maintains perfusion pressure but places additional strain on the injured heart. Efforts should be made to lower afterload provided that systemic blood pressure is maintained (table III).

\subsubsection{Oxygen Consumption}

Positive pressure mechanical ventilation will serve to decrease left ventricular afterload, ${ }^{[68-70]}$ as well as decrease work of breathing, and thus oxygen consumption. Adequate sedation will also decrease oxygen consumption, and occasionally neuromuscular blockade is necessary to stabilize the patient.

\subsubsection{Mechanical Support}

Patients who still have signs of inadequate end organ perfusion despite optimization of hemodynamics and immunomodulation (see below), and are thought to have reversible ventricular dysfunction, may be considered for mechanical cardiac support. However, the reported pediatric experiences with extracorporeal membranous oxygenation and ventricular assist devices are lim- ited to nontransplant patients, or those in the immediate posttransplant period. ${ }^{[71,72]}$ Limited adult experience with mechanical support in the setting of rejection is discouraging. ${ }^{[73]}$

\subsection{Immunosuppression}

Concurrent with the measures outlined above, augmentation of immune suppression to facilitate myocardial recovery is crucial in the treatment of pediatric heart transplant patients with severe hemodynamic compromise due to rejection. Obtaining a myocardial biopsy is helpful to differentiate cellular from humoral rejection if the patient is hemodynamically stable. Because the severity of rejection found on biopsy does not always correlate with hemodynamic changes, the immunotherapy prescribed depends on several other factors, including severity of symptoms, time since transplant, grade of rejection on prior biopsies, and baseline immunosuppression. Adolescent patients will often admit to noncompliance with medications. ${ }^{[2]}$

\subsubsection{Cellular Rejection}

Cellular rejection is the most common form of rejection seen in pediatric heart transplant recipients, and is graded based on criteria endorsed by the International Society for Heart and Lung Transplantation. ${ }^{[74]}$ The cornerstone of treatment for cellular rejection is pulsed dose corticosteroids. ${ }^{[56]}$ Patients with severe hemodynamic compromise may have grade 3 or 4 rejection on myocardial biopsy, and will receive methylprednisolone 10 $\mathrm{mg} / \mathrm{kg} / \mathrm{day}$ IV for 3 to 5 days. The use of a corticosteroid taper is controversial, but is generally used in our institution in patients with severe hemodynamic compromise requiring inotropic therapy. ${ }^{[75]}$ A follow-up myocardial biopsy may be obtained in 7 to 10 days.

Based on uncontrolled data in adult patients with refractory rejection, ${ }^{[76-79]}$ pediatric heart transplant recipients with rejection and hemodynamic compromise requiring inotropic support in our institution receive muromonab-CD3 $(0.1 \mathrm{mg} / \mathrm{kg} /$ day for 10 to 14

Table III. Selected intravenous agents useful in pediatric heart transplant patients with severe hemodynamic compromise

\begin{tabular}{llll}
\hline Drug & $\begin{array}{l}\text { Administration range } \\
(\mu \mathrm{g} / \mathrm{kg} / \mathrm{min})\end{array}$ & Mechanism of action & Predominant clinical effect \\
\hline Dobutamine & $1-20$ & $\beta_{1}$-agonist & Inotrope, mild chronotropy \\
Dopamine & $1-3$ & Dopaminergic agonist & $\beta_{1}$-agonist \\
& $4-10$ & $\alpha$-agonist $>\beta$ & Renal vasodilator \\
& $11-20$ & $\alpha, \beta_{1+2}$-agonist & Inotrope \\
Epinephrine (adrenaline) & $0.03-1$ & & Vasoconstriction \\
& & Inotrope, chronotrope, $\beta_{2}$ vasodilation at lower doses, \\
Milrinone & $0.25-0.75+/-$ loading dose & Phosphodiesterase-III inhibitor & vasoconstriction at higher doses \\
Nitroprusside & $0.5-10$ & Nitric oxide donor & Vasodilation \\
Enalaprilat & $0.01-0.3 \mathrm{mg} / \mathrm{kg} \mathrm{IV} \mathrm{q6h}$ & Angiotensin converting enzyme inhibitor & Systemic vasodilation \\
\hline$\alpha=\alpha$ ratilor
\end{tabular}

$\alpha=\alpha$ receptor; $\beta=\beta$ receptor; $\mathbf{I V}=$ intravenously; $\mathbf{q} \mathbf{6 h}=$ every 6 hours. 
days). The efficacy of muromonab-CD3 in this setting has been questioned. ${ }^{[80]}$

Augmentation of maintenance immunosuppression should be considered in patients with hemodynamic compromise. Mycophenolate mofetil may be substituted for azathioprine, ${ }^{[81]}$ and tacrolimus may replace cyclosporine. ${ }^{[82,83]}$ Methotrexate has also been found to be efficacious in a small, uncontrolled pediatric study of infants with 'life-threatening' rejection ${ }^{[84]}$ Methotrexate is a folic acid analog that blocks the conversion of dihydrofolic acid to tetrafolic acid, thus inhibiting purine synthesis and cell division. Neutropenia and gastritis are common adverse effects.

\subsubsection{Humoral Rejection}

Humoral rejection in heart transplant recipients is confirmed when biopsies reveal endothelial swelling and vasculitis by light microscopy, as well as vascular deposition of immunoglobulin and complement by immunofluorescence. ${ }^{[85]}$ When compared with cellular rejection, humoral rejection occurs earlier following transplant, causes more hemodynamic compromise, and is associated with earlier development of TCAD and higher mortality. ${ }^{[85-87]}$ Humoral rejection may be graded based on criteria published by Olsen et al. ${ }^{[88]}$ Graft dysfunction is exacerbated by thrombosis and vasospasm of coronary arteries. Although most of the literature on humoral rejection in heart transplantation is based on adult patients, humoral rejection has been reported in children from our center. ${ }^{[89]}$

Treatments employed for humoral rejection are prescribed with the intention of suppressing new antibody formation, removing circulating antibody, and improving coronary blood flow. Often a combination of agents are employed to reduce new antibody formation, including high dose corticosteroids, cyclophosphamide (starting at $2 \mathrm{mg} / \mathrm{kg} / \mathrm{day}$ ), antithymocyte globulin, and muromonab-CD3. ${ }^{[86,88,90]}$

Antibody removal for humoral rejection is accomplished with plasmapheresis, the efficacy of which has been reported in an animal model, ${ }^{[91]}$ and several adult case reports and small, uncontrolled series. ${ }^{[86,88,92-95]} \mathrm{We}$ reported seven episodes in five young transplant patients with severe late left ventricular failure, negative immunoflourescence, and variable grade cellular rejection on myocardial biopsy. ${ }^{[96]}$ Despite not meeting strict criteria for humoral rejection, these critically ill patients were all successfully treated with aggressive multimodal immunomodulation, including corticosteroids, muromonab-CD3, cyclophosphamide, and plasmapheresis.

Thus, we advocate consideration of plasmapheresis, even in the absence of positive immunoflourescence, in pediatric patients with late severe hemodynamic compromise. If elevated at the time of presentation, panel reactive antibody levels may be followed to determine duration of plasmapheresis treatment, but we recommend a minimum of three treatments either daily or every other day. Ionized calcium levels should be normalized prior to starting plasmapheresis to avoid hypotension. Extracorporeal immunoabsorption may be considered as an alternative to plasmapheresis for removing circulating IgG, but experience is limited. ${ }^{[97]}$

Heparin infusions may prevent further coronary thrombosis in patients with 'true' humoral rejection, although no controlled studies have been reported to evaluate the efficacy of heparin in this setting. ${ }^{[86,88]}$ Furthermore, there are no data in the literature regarding the use of thrombolytic agents in this setting.

\subsubsection{Retransplantation}

A pediatric heart transplant recipient with severe hemodynamic compromise secondary to acute rejection who has not responded to the above supportive measures may be considered for retransplantation; ${ }^{[98,99]}$ however, many such patients will have developed multi-organ system failure or infection, making them poor surgical candidates.

\section{Conclusions}

A major goal of medical personnel caring for pediatric heart transplant recipients is the prevention of rejection, which may lead to graft failure. Triple-drug immunosuppression strategies are initially used by most pediatric centers in the first months following transplant to prevent rejection. Preliminary data question the role of corticosteroids in the long-term management of heart transplant recipients. Induction immunotherapy holds promise to prevent acute rejection but requires further study. Allograft rejection is a leading cause of severe hemodynamic compromise in heart transplant patients. Intensive monitoring and inotropic support are necessary to maintain end organ function in such patients, while additional immunosuppressive strategies are employed to reverse allograft cellular and/or humoral rejection.

\section{Acknowledgments}

The authors have provided no information on sources of funding or on conflicts of interest directly relevant to the content of this review.

\section{References}

1. Pahl E, Naftel DC, Canter CE, et al. Death after rejection with severe hemodynamic compromise in pediatric heart transplant recipients: a multi-institutional study. J Heart Lung Transplant 2001; 20 (3): 279-87

2. Ringewald JM, Gidding SS, Crawford SE, et al. Nonadherence is associated with late rejection in pediatric heart transplant recipients. J Pediatr 2001; 139 (1): $75-8$

3. Denton MD, Magee CC, Sayegh MH. Immunosuppressive strategies in transplantation. Lancet 1999; 353 (9158): 1083-91

4. Liu J, Farmer Jr JD, Lane WS, et al. Calcineurin is a common target of cyclophilincyclosporin A and FKBP-FK506 complexes. Cell 1991; 66 (4): 807-15

5. Kahan BD. Cyclosporine. N Engl J Med 1989; 321 (25): 1725-38 
6. Carrier M, White M, Pellerin M, et al. Comparison of neoral and sandimmune cyclosporine for induction of immunosuppression after heart transplantation. Can J Cardiol 1997; 13 (5): 469-73

7. White M, Pelletier GB, Tan A, et al. Pharmacokinetic, hemodynamic, and metabolic effects of cyclosporine sandimmune versus the microemulsion neoral in heart transplant recipients. J Heart Lung Transplant 1997; 16 (8): 787-94

8. Shah MB, Martin JE, Schroeder TJ, et al. The evaluation of the safety and tolerability of two formulations of cyclosporine - neoral and sandimmune: a metaanalysis. Transplantation 1999; 67 (11): 1411-7

9. Taylor DO, Barr ML, Radovancevic B, et al. A randomized, multicenter comparison of tacrolimus and cyclosporine immunosuppressive regimens in cardiac transplantation: decreased hyperlipidemia and hypertension with tacrolimus. J Heart Lung Transplant 1999; 18 (4): 336-45

10. Asante-Korang A, Boyle GJ, Webber SA, et al. Experience of FK506 immune suppression in pediatric heart transplantation: a study of long-term adverse effects. J Heart Lung Transplant 1996; 15 (4): 415-22

11. Paolillo JA, Boyle GJ, Law YM, et al. Posttransplant diabetes mellitus in pediatric thoracic organ recipients receiving tacrolimus-based immunosuppression. Transplantation 2001; 71 (2): 252-6

12. Dobrolet NC, Webber SA, Blatt J, et al. Hematologic abnormalities in children and young adults receiving tacrolimus-based immunosuppression following cardiothoracic transplantation. Pediatr Transplant 2001; 5 (2): 125-31

13. Boucek MM, Faro A, Novick RJ, et al. The Registry of the International Society for Heart and Lung Transplantation: fourth official pediatric report, 2000. J Heart Lung Transplant 2001; 20 (1): 39-52

14. Robinson BV, Boyle GJ, Miller SA, et al. Optimal dosing of intravenous tacrolimus following pediatric heart transplantation. J Heart Lung Transplant 1999; 18 (8): 786-91

15. Allison AC, Eugui EM. Immunosuppressive and other effects of mycophenolic acid and an ester prodrug, mycophenolate mofetil. Immunol Rev 1993; 136: 5-28

16. Sievers TM, Rossi SJ, Ghobrial RM, et al. Mycophenolate mofetil. Pharmacotherapy 1997; 17 (6): 1178-97

17. Eugui EM, Almquist SJ, Muller CD, et al. Lymphocyte-selective cytostatic and immunosuppressive effects of mycophenolic acid in vitro: role of deoxyguanosine nucleotide depletion. Scand J Immunol 1991; 33 (2): 161-73

18. Allison AC, Kowalski WJ, Muller CJ, et al. Mycophenolic acid and brequinar, inhibitors of purine and pyrimidine synthesis, block the glycosylation of adhesion molecules. Transplant Proc 1993; 25 (3 Suppl. 2): 67-70

19. Kobashigawa J, Miller L, Renlund D, et al. A randomized active-controlled trial of mycophenolate mofetil in heart transplant recipients. Mycophenolate Mofetil Investigators. Transplantation 1998; 66 (4): 507-15

20. Seebacher G, Weigel G, Griesmacher A, et al. One and a half years of experience with mycophenolate mofetil (Cellcept) in cardiac transplantation: a prospective, randomized study. Transplant Proc 1999; 31 (8): 3291-3

21. Dipchand AI, Pietra B, McCrindle BW, et al. Mycophenolic acid levels in pediatric heart transplant recipients receiving mycophenolate mofetil. J Heart Lung Transplant 2001; 20 (10): 1035-43

22. Dipchand AI, Benson L, McCrindle BW, et al. Mycophenolate mofetil in pediatric heart transplant recipients: a single-center experience. Pediatr Transplant 2001; 5 (2): $112-8$

23. Kuo CJ, Chung J, Fiorentino DF, et al. Rapamycin selectively inhibits interleukin-2 activation of p70 S6 kinase. Nature 1992; 358 (6381): 70-3

24. Terada N, Lucas JJ, Szepesi A, et al. Rapamycin inhibits the phosphorylation of p70 S6 kinase in IL-2 and mitogen-activated human T cells. Biochem Biophys Res Commun 1992; 186 (3): 1315-21

25. MacDonald AS. A worldwide, phase III, randomized, controlled, safety and efficacy study of a sirolimus/cyclosporine regimen for prevention of acute rejection in recipients of primary mismatched renal allografts. Transplantation 2001; 71 (2): $271-80$

26. Hong JC, Kahan BD. A calcineurin antagonist-free induction strategy for immunosuppression in cadaveric kidney transplant recipients at risk for delayed graft function. Transplantation 2001; 71 (9): 1320-8
27. Snell GI, Levvey B, Chin W, et al. Sirolimus (rapamycin) allows renal recovery in lung and heart transplant recipients with chronic renal impairment. J Heart Lung Transplant 2001; 20 (2): 163-4

28. Scudeletti M, Castagnetta L, Imbimbo B, et al. New glucocorticoids: mechanisms of immunological activity at the cellular level and in the clinical setting. Ann NY Acad Sci 1990; 595: 368-82

29. Scheinman RI, Cogswell PC, Lofquist AK, et al. Role of transcriptional activation of I kappa B alpha in mediation of immunosuppression by glucocorticoids Science 1995; 270 (5234): 283-6

30. Auphan N, DiDonato JA, Rosette C, et al. Immunosuppression by glucocorticoids: inhibition of NF-kappa B activity through induction of I kappa B synthesis. Science 1995; 270 (5234): 286-90

31. Ferrazzi P, Fiocchi R, Gamba A, et al. Pediatric heart transplantation without chronic maintenance steroids. J Heart Lung Transplant 1993; 12 (6 Pt 2): S241-5

32. Canter CE, Moorhead S, Saffitz JE, et al. Steroid withdrawal in the pediatric heart transplant recipient initially treated with triple immunosuppression. J Heart Lung Transplant 1994; 13 (1 Pt 1): 74-9

33. Reinherz EL, Kung PC, Goldstein G, et al. A monoclonal antibody with selective reactivity with functionally mature human thymocytes and all peripheral human T cells. J Immunol 1979; 123 (3): 1312-7

34. Van Wauwe JP, De Mey JR, Goossens JG. OKT3: a monoclonal anti-human T lymphocyte antibody with potent mitogenic properties. J Immunol 1980; 124 (6): $2708-13$

35. Gilbert EM, Eiswirth CC, Renlund DG, et al. Use of orthoclone OKT3 monoclonal antibody in cardiac transplantation: early experience with rejection prophylaxis and treatment of refractory rejection. Transplant Proc 1987; 19 (2 Suppl. 1): 45-53

36. Landegren U, Ramstedt U, Axberg I, et al. Selective inhibition of human T cell cytotoxicity at levels of target recognition or initiation of lysis by monoclonal OKT3 and Leu-2a antibodies. J Exp Med 1982; 155 (5): 1579-84

37. Bonnefoy-Berard N, Revillard JP. Mechanisms of immunosuppression induced by antithymocyte globulins and OKT3. J Heart Lung Transplant 1996; 15 (5): 435-42

38. Breisblatt WM, Schulman DS, Stein K, et al. Hemodynamic response to OKT3 in orthotopic heart transplant recipients: evidence for reversible myocardial dysfunction. J Heart Lung Transplant 1991; 10 (3): 359-65

39. Chatenoud L, Ferran C, Reuter A, et al. Systemic reaction to the anti-T-cell monoclonal antibody OKT3 in relation to serum levels of tumor necrosis factor and interferon-gamma [corrected]. N Engl J Med 1989; 320 (21): 1420-1

40. Hosenpud JD, Norman DJ, Pantely GA, et al. OKT3-induced hypotension in heart allograft recipients treated for steroid-resistant rejection. J Heart Transplant 1989; 8 (2): 159-65

41. van Gelder T, Balk AH, Jonkman FA, et al. A randomized trial comparing safety and efficacy of OKT3 and a monoclonal anti-interleukin-2 receptor antibody (BT563) in the prevention of acute rejection after heart transplantation. Transplantation 1996; 62 (1): 51-5

42. O'Connell JB, Renlund DG, Hammond EH, et al. Sensitization to OKT3 monoclonal antibody in heart transplantation: correlation with early allograft loss. J Heart Lung Transplant 1991; 10 (2): 217-21

43. Hammond EH, Wittwer CT, Greenwood J, et al. Relationship of OKT3 sensitization and vascular rejection in cardiac transplant patients receiving OKT3 rejection prophylaxis. Transplantation 1990; 50 (5): 776-82

44. Kobashigawa JA, Stevenson LW, Brownfield E, et al. Does short-course induction with OKT3 improve outcome after heart transplantation: a randomized trial. J Heart Lung Transplant 1993; 12 (2): 205-8

45. Swinnen LJ, Costanzo-Nordin MR, Fisher SG, et al. Increased incidence of lymphoproliferative disorder after immunosuppression with the monoclonal antibody OKT3 in cardiac-transplant recipients. N Engl J Med 1990; 323 (25): 1723-8

46. Johnson MR, Mullen GM, O'Sullivan EJ, et al. Risk/benefit ratio of perioperative OKT3 in cardiac transplantation. Transplant Proc 1993; 25 (1 Pt 2): 1149-51 
47. Kirklin JK, Bourge RC, White-Williams C, et al. Prophylactic therapy for rejection after cardiac transplantation: a comparison of rabbit antithymocyte globulin and OKT3. J Thorac Cardiovasc Surg 1990; 99 (4): 716-24

48. Boucek Jr RJ, Naftel D, Boucek MM, et al. Induction immunotherapy in pediatric heart transplant recipients: a multicenter study. J Heart Lung Transplant 1999; 18 (5): 460-9

49. Nashan B, Moore R, Amlot P, et al. Randomised trial of basiliximab versus placebo for control of acute cellular rejection in renal allograft recipients. CHIB 201 International Study Group. Lancet 1997; 350 (9086): 1193-8

50. Kahan BD, Rajagopalan PR, Hall M. Reduction of the occurrence of acute cellular rejection among renal allograft recipients treated with basiliximab, a chimeric anti-interleukin-2-receptor monoclonal antibody. United States Simulect Renal Study Group. Transplantation 1999; 67 (2): 276-84

51. Vincenti F, Kirkman R, Light S, et al. Interleukin-2-receptor blockade with daclizumab to prevent acute rejection in renal transplantation. Daclizumab Triple Therapy Study Group. N Engl J Med 1998; 338 (3): 161-5

52. Beniaminovitz A, Itescu S, Lietz K, et al. Prevention of rejection in cardiac transplantation by blockade of the interleukin-2 receptor with a monoclonal antibody. N Engl J Med 2000; 342 (9): 613-9

53. Wolfe JT, Lessin SR, Singh AH, et al. Review of immunomodulation by photopheresis: treatment of cutaneous T-cell lymphoma, autoimmune disease, and allograft rejection. Artif Organs 1994; 18 (12): 888-97

54. Barr ML, McLaughlin SN, Murphy MP, et al. Prophylactic photopheresis and effect on graft atherosclerosis in cardiac transplantation. Transplant Proc 1995; 27 (3): 1993-4

55. Barr ML, Meiser BM, Eisen HJ, et al. Photopheresis for the prevention of rejection in cardiac transplantation. Photopheresis Transplantation Study Group. N Engl J Med 1998; 339 (24): 1744-51

56. McNamara D, Di Salvo T, Mathier M, et al. Left ventricular dysfunction after heart transplantation: incidence and role of enhanced immunosuppression. J Heart Lung Transplant 1996; 15 (5): 506-15

57. Friedman WF, George BL. Treatment of congestive heart failure by altering loading conditions of the heart. J Pediatr 1985; 106 (5): 697-706

58. Hoffman JIE. Structure and function of the heart. In: Fuhrman BP, Zimmerman JJ, editors. Pediatric critical care. St Louis (MO): Mosby Year Book, 1992: 215-8

59. Deal BJ, Wolff GS, Gelband H, editors. Current concepts in diagnosis and management of arrhythmias in infants and children. Armonk (NY): Futura Publishing Company, Inc., 1998

60. Dreyer WJ, Mayer DC, Neish SR. Cardiac contractility and pump function. In: Garson Jr A, Brucker JT, Fisher DJ, et al., editors. The science and practice of pediatric cardiology. Baltimore (MD): Williams and Wilkins, 1998: 211-20

61. Bohn DJ, Poirier CS, Edmonds JF, et al. Hemodynamic effects of dobutamine after cardiopulmonary bypass in children. Crit Care Med 1980; 8 (7): 367-71

62. Habib DM, Padbury JF, Anas NG, et al. Dobutamine pharmacokinetics and pharmacodynamics in pediatric intensive care patients. Crit Care Med 1992; 20 (5): 601-8

63. Berg RA, Donnerstein RL, Padbury JF. Dobutamine infusions in stable, critically ill children: pharmacokinetics and hemodynamic actions. Crit Care Med 1993; 21 (5): 678-86

64. Chang AC, Atz AM, Wernovsky G, et al. Milrinone: systemic and pulmonary hemodynamic effects in neonates after cardiac surgery. Crit Care Med 1995; 23 (11): 1907-14

65. Bailey JM, Miller BE, Lu W, et al. The pharmacokinetics of milrinone in pediatric patients after cardiac surgery. Anesthesiology 1999; 90 (4): 1012-8

66. Tobin JR, Wetzel RC. Shock and multi-organ system failure. In: Rogers MC, editor. Textbook of pediatric intensive care. Baltimore (MD): Williams and Wilkins, 1996: 590-3

67. Wessel DL. Managing low cardiac output syndrome after congenital heart surgery. Crit Care Med 2001; 29 (10 Suppl.): S220-30

68. Grace MP, Greenbaum DM. Cardiac performance in response to PEEP in patients with cardiac dysfunction. Crit Care Med 1982; 10 (6): 358-60
69. Mathru M, Rao TL, El-Etr AA, et al. Hemodynamic response to changes in ventilatory patterns in patients with normal and poor left ventricular reserve. Crit Care Med 1982; 10 (7): 423-6

70. Pinsky MR, Summer WR. Cardiac augmentation by phasic high intrathoracic pressure support in man. Chest 1983; 84 (4): 370-5

71. Duncan BW, Hraska V, Jonas RA, et al. Mechanical circulatory support in children with cardiac disease. J Thorac Cardiovasc Surg 1999; 117 (3): 529-42

72. Duncan BW, Bohn DJ, Atz AM, et al. Mechanical circulatory support for the treatment of children with acute fulminant myocarditis. J Thorac Cardiovasc Surg 2001; 122 (3): 440-8

73. Arafa O, Fiane AE, Svennevig JL, et al. Mechanical circulatory support of heart transplant patients. Transplant Proc 2001; 33 (1-2): 1603-4

74. Billingham ME, Cary NR, Hammond ME, et al. A working formulation for the standardization of nomenclature in the diagnosis of heart and lung rejection: Heart Rejection Study Group. The International Society for Heart Transplantation. J Heart Transplant 1990; 9 (6): 587-93

75. Lonquist JL, Radovancevic B, Vega JD, et al. Re-evaluation of steroid tapering after steroid pulse therapy for heart rejection. J Heart Lung Transplant 1992; 11 (5): 913-9

76. Gilbert EM, Dewitt CW, Eiswirth CC, et al. Treatment of refractory cardiac allograft rejection with OKT3 monoclonal antibody. Am J Med 1987; 82 (2): 202-6

77. Haverty TP, Sanders M, Sheahan M. OKT3 treatment of cardiac allograft rejection. J Heart Lung Transplant 1993; 12 (4): 591-8

78. O'Connell JB, Renlund DG, Gay Jr WA, et al. Efficacy of OKT3 retreatment for refractory cardiac allograft rejection. Transplantation 1989; 47 (5): 788-92

79. Cantarovich M, Latter DA, Loertscher R. Treatment of steroid-resistant and recurrent acute cardiac transplant rejection with a short course of antibody therapy. Clin Transpl 1997; 11 (4): 316-21

80. Wagner FM, Reichenspurner H, Uberfuhr P, et al. How successful is OKT3 rescue therapy for steroid-resistant acute rejection episodes after heart transplantation. J Heart Lung Transplant 1994; 13 (3): 438-42

81. Kirklin JK, Bourge RC, Naftel DC, et al. Treatment of recurrent heart rejection with mycophenolate mofetil (RS-61443): initial clinical experience. J Heart Lung Transplant 1994; 13 (3): 444-50

82. Onsager DR, Canver CC, Jahania MS, et al. Efficacy of tacrolimus in the treatment of refractory rejection in heart and lung transplant recipients. J Heart Lung Transplant 1999; 18 (5): 448-55

83. Yamani MH, Starling RC, Pelegrin D, et al. Efficacy of tacrolimus in patients with steroid-resistant cardiac allograft cellular rejection. J Heart Lung Transplant 2000; 19 (4): 337-42

84. Bouchart F, Gundry SR, Van Schaack-Gonzales J, et al. Methotrexate as rescue/ adjunctive immunotherapy in infant and adult heart transplantation. J Heart Lung Transplant 1993; 12 (3): 427-33

85. Hammond EH, Yowell RL, Nunoda S, et al. Vascular (humoral) rejection in heart transplantation: pathologic observations and clinical implications. J Heart Transplant 1989; 8 (6): 430-43

86. Miller LW, Wesp A, Jennison $\mathrm{SH}$, et al. Vascular rejection in heart transplant recipients. J Heart Lung Transplant 1993; 12 (2): S147-52

87. Hammond EH, Yowell RL, Price GD, et al. Vascular rejection and its relationship to allograft coronary artery disease. J Heart Lung Transplant 1992; 11 (3 Pt 2): S111-9

88. Olsen SL, Wagoner LE, Hammond EH, et al. Vascular rejection in heart transplantation: clinical correlation, treatment options, and future considerations. J Heart Lung Transplant 1993; 12 (2): S135-42

89. Zales VR, Crawford S, Backer CL, et al. Spectrum of humoral rejection after pediatric heart transplantation. J Heart Lung Transplant 1993; 12 (4): 563-71

90. Costanzo-Nordin MR, Heroux AL, Radvany R, et al. Role of humoral immunity in acute cardiac allograft dysfunction. J Heart Lung Transplant 1993; 12 (2): S143-6

91. Grauhan O, Muller J, von Baeyer H, et al. Treatment of humoral rejection after heart transplantation. J Heart Lung Transplant 1998; 17 (12): 1184-94

92. Schuurman HJ, Jambroes G, Borleffs JC, et al. Acute humoral rejection in a heart transplant recipient. Transplant Proc 1989; 21 (1 Pt 3): 2529-30 
93. Partanen J, Nieminen MS, Krogerus L, et al. Heart transplant rejection treated with plasmapheresis. J Heart Lung Transplant 1992; 11 (2 Pt 1): 301-5

94. Ratkovec RM, Hammond EH, O'Connell JB, et al. Outcome of cardiac transplant recipients with a positive donor-specific crossmatch: preliminary results with plasmapheresis. Transplantation 1992; 54 (4): 651-5

95. Berglin E, Kjellstrom C, Mantovani V, et al. Plasmapheresis as a rescue therapy to resolve cardiac rejection with vasculitis and severe heart failure: a report of five cases. Transpl Int 1995; 8 (5): 382-7

96. Pahl E, Crawford SE, Cohn RA, et al. Reversal of severe late left ventricular failure after pediatric heart transplantation and possible role of plasmapheresis. Am J Cardiol 2000; 85: 735-9
97. Olivari MT, May CB, Johnson NA, et al. Treatment of acute vascular rejection with immunoadsorption. Circulation 1994; 90 (5 Pt II): II70-3

98. Michler RE, Edwards NM, Hsu D, et al. Pediatric retransplantation. J Heart Lung Transplant 1993; 12 (6 Pt 2): S319-27

99. Dearani JA, Razzouk AJ, Gundry SR, et al. Pediatric cardiac retransplantation: intermediate-term results. Ann Thorac Surg 2001; 71 (1): 66-70

Correspondence and offprints: Dr Elfriede Pahl, Heart Transplant Program, The Children's Memorial Hospital, 2300 Children's Plaza, Box 21, Chicago, IL 60614, USA. 